\title{
GERAKAN PENGENDALIAN HAMA DAN PENYAKIT TANAMAN PADI OLEH DINAS PERTANIAN KETAHANAN PANGAN DAN PERIKANAN KABUPATEN KLATEN
}

\section{MOVEMENT ON PEST AND DISEASES CONTROL IN RICE PLANT BY DEPARTMENT OF AGICULTURE, FOOD, AND FISHERIES AT KLATEN REGENCY}

\author{
Ariel Sukma Mahendra Darmanto ${ }^{1)}$ dan Suprihati ${ }^{1)}$ \\ ${ }^{1)}$ Prodi Agroteknologi, Fakultas Pertanian dan Bisnis, \\ Universitas Kristen Satya Wacana \\ email: 512017022@student.uksw.edu
}

\begin{abstract}
ABSTRAK
Dinas Pertanian, Ketahanan Pangan, dan Perikanan (DPKPP) Kabupaten Klaten merupakan kedinasan dengan salah satu tupoksi tugas menyelenggarakan pengendalian hama penyakit pada tanaman pangan. Tujuan penelitian adalah untuk mengetahui cara pengendalian hama dan penyakit pada tanaman padi di Kabupaten Klaten. Penelitian dilakukan pada 4 Januari - 4 April 2021 di wilayah Kabupaten Klaten dengan metode praktik, wawancara dan studi pustaka. Hama dan penyakit utama tanaman padi di Kabupaten Klaten ialah: penggerek batang, tikus, wereng batang coklat, blas, dan BLB. Gerakan pengendalian hama dan penyakit tanaman di Kabupaten Klaten mendukung empat konsep utama PHT dipelopori oleh Petugas Pengamat Organisme Pengganggu Tanaman - Pengamat Hama Penyakit (POPT PHP) dengan melakukan Gerakan pengendalian (gerdal) melalui koordinasi bersama Petugas Penyuluh Lapang (PPL) dan kelompok tani setempat. Gerakan pengendalian yang dilakukan dominan menggunakan pestisida kimia dengan berbagai macam bahan aktif tergantung dari hama dan penyakit yang dituju. Selain pestisida kimia juga digunakan agensia hayati seperti Beauveria bassiana untuk menangani hama wereng batang coklat dan penggerek batang dan Tricodherma untuk mengatasi penyakit blas. Selain melakukan gerdal DPKPP juga melaksanakan penyuluhan dan mengadakan program Sekolah Lapang Pengendalian Hama Terpadu (SLPHT) bagi petani serta memberikan bantuan bibit padi guna mendukung konsep PHT budidaya tanaman sehat. Gerdal yang dilakukan DPKPP Kabupaten Klaten sudah mendukung empat konsep utama Pengendalian Hama Terpadu (PHT) tetapi masih banyak menggunakan pestisida kimia serta minim pemanfaatan musuh alami seperti melakukan penanaman refugia maupun pembuatan rumah burung hantu (RUBUHA).
\end{abstract}

Kata Kunci: hama; Klaten; padi; penyakit; PHT

\section{ABSTRACT}

Department of agriculture, food security, and fisheries (DPKPP) Klaten district is an agency to organize controlling of crops pest. The purpose of this research is to determine how to control paddy pest and disease in klaten regency. This research was conducted in January $4^{\text {th }}-$ March $4^{\text {th }}$ in Klaten Regency using praxis, interview, and literature review method. There are five main pests and diseases in Klaten regency, which are: stem borer, rat, brown plant hopper, blas, and BLB. Pests and plant diseases control in Klaten Regency is carried out by 
Plant Pest Organism Obervers-Pest Disease Observers (POPT-PHP) by doing movement control through coordination with field extension officer and local group farmers. Movement control has supported four main concepts of integrated pest management (IPM) but still using a lot of pesticide. The control movement dominantly using chemical pesticides with many variety of active ingredients depend on what pest and disease which became the target. Besides chemical pesticide, biological agents are also used such as Beauveria bassiana to handle brown plant hopper and stem borer, and Tricodherma to handle blas disease. Besides movement control, DPKPP also perform counselling, organizing Integrated Field Pest Control School (SPLHT) program for farmers and provide seeds assistance to support PHT concept which is cultivating healthy plants. Movement control conducted by DPKPP Klaten district has supported four main oncepts of PHT but still using many chemical pesticide and lack of utilization of natural enemies like refugia planting and owl house building (RUBUHA)

Keywords: disease; Klaten; paddy; pest; IPM

\section{PENDAHULUAN}

Indonesia merupakan negara dengan sekitar 90\% penduduk pengonsumsi beras sebagai makanan pokok. Konsumsi beras per kapita mencapai $113 \mathrm{~kg}$ setara dengan konsumsi beras nasional sebesar 27 juta ton per tahun (Prakosta, et al., 2017).

Tahun 2019 Provinsi Jawa Tengah merupakan produsen beras tertinggi di Indonesia dengan produksi sebanyak 9.665.654 ton gabah kering giling atau setara dengan 5.523.969 ton beras (Anonim, 2020a). Kabupaten Klaten menempati peringkat dua belas dalam produksi padi di Provinsi Jawa Tengah pada tahun 2019 (Anonim, 2020b).
Kabupaten Klaten secara administratif terdiri atas 26 kecamatan, 10 kelurahan, dan 401 desa dengan total luas wilayah sebesar 655.560.000 Ha dengan luas areal panen tanaman padi sebesar 69.557 Ha (Anonim, 2020b). Berdasarkan data Badan Pusat Statistik Kabupaten Klaten (Anonim, 2020a) produksi padi pada Kabupaten Klaten sebesar 469.863 ton.

Indonesia memiliki iklim tropis dan budidaya padi yang dilakukan sepanjang tahun merupakan kombinasi yang optimal untuk perkembangan hama (Siregar dan Nasution, 2019). Hama merupakan faktor utama penghambat budidaya padi yang dapat menyebabkan penurunan rata-rata produksi. Hama 
yang kerap dijumpai menyerang tanaman padi adalah penggerek batang padi, wereng coklat atau hijau, walang sangit, keong mas, tikus, dan burung. (Manueke et al, 2017).

Hama utama tikus mengakibatkan kehilangan padi di Indonesia dapat mencapai $200.000-$ 300.000 ton per tahun. (Ratnasih, et $a l .$, 2020). Hasil produksi yang lebih rendah ini disebabkan oleh intensitas serangan hama yang tinggi. (Wilyus dan Yunita, 2016). Berdasarkan data Balai Besar Tanaman Padi pada tahun 2003 luas panen padi Indonesia mencapai 11,48 juta hektar dan produksi padi mencapai 52,08 juta ton. Data ini mengungkapkan terjadinya peningkatan produksi dari tahun 2002 dengan hasil 51,49 juta ton. Peningkatan ini terjadi karena adanya penerapan teknologi pengendalian hama dan penyakit (Jayati, 2011).

Kabupaten Klaten menjadi salah satu sentra produksi padi di Indonesia pada urutan ke 12 produksi padi di Jawa Tengah yang menempati peringkat pertama produksi padi nasional. Oleh karena itu perlu dilakukan pengamatan dan penanganan hama yang tepat dan efektif guna mendukung kelestarian produktivitas padi din Kabupaten Klaten. Penelitian ini bertujuan untuk mengetahui cara penanganan dan pengendalian hama padi oleh Dinas Pertanian, Ketahanan Pangan, dan Perikanan Kabupaten Klaten sebagai instansi pemerintah yang bertanggung jawab dan dapat memberikan saran pengendalian yang lebih efektif untuk masa mendatang.

\section{METODE}

Penelitian dilakukan pada 4 Januari - 4 April 2021 di Kabupaten Klaten dan Dinas Pertanian, Ketahanan Pangan, dan Perikanan dengan tanaman padi sebagai objek utama menggunakan metode praktik, wawancara, dan studi pustaka. Jenis data yang digunakan adalah data primer dan sekunder. Responden yang digunakan adalah pegawai DPKPP Kabupaten Klaten, petugas POPT-PHP, petugas PPL, dan petani setempat. Data dikumpulkan dengan teknik pengamatan, wawancara, dan studi dokumentasi.

\section{HASIL DAN PEMBAHASAN}

Pengendalian hama dan penyakit padi di kawasan 
administratif Kabupaten Klaten dilakukan oleh petugas POPT-PHP (Pengendali Organisme Pengganggu Tanaman - Pengamat Hama dan Penyakit) dengan tupoksi tugas pengamatan guna mengetahui populasi dan intensitas serangan OPT serta keberadaan musuh alaminya. Pengamatan yang dilakukan dapat menjadi pedoman pengendalian hama dan dasar prediksi OPT mendatang. Petugas POPT-PHP menjadi ujung tombak pengendalian hama dan penyakit pada tanaman padi, pasalnya selain melakukan pengamatan rutin petugas POPT juga memiliki tugas untuk berkoordinasi dengan kelompok tani dari setiap wilayah yang ditugaskan kepada setiap petugas. Petugas POPT-PHP memiliki wilayah tugas yang mencakup satu atau lebih kecamatan di wilayah administratif Kabupaten Klaten. Petugas POPTPHP tiap kecamatan dikomandoi oleh seorang POPT-PHP yang menjadi koordinator POPT Kabupaten Klaten.

Tabel 1. Penanggung Jawab POPT Kecamatan, Kabupaten Klaten

\begin{tabular}{clllll}
\hline No & \multicolumn{1}{c}{ Kecamatan } & \multicolumn{1}{c}{ POPT_PHP } & No & \multicolumn{1}{c}{ Kecamatan } & \multicolumn{1}{c}{ POPT_PHP } \\
\hline 1. & Prambanan & Prayoga & 14 & Pedan & Joko \\
2. & Gantiwarno & Romdloni & 15 & Karangdowo & Sujimin \\
3. & Wedi & Krisdianto & 16 & Juwiring & Sasongko \\
4 & Bayat & Krisdianto & 17 & Wonosari & Joko \\
5 & Cawas & Sujimin & 18 & Delanggu & Sasongko \\
6 & Trucuk & Abdul Azis & 19 & Polanharjo & Kisbianto \\
7 & Kalikotes & Heru & 20 & Karanganom & Adi Kurniawan \\
8 & Kebonarum & Sari Setyaningsih & 21 & Tulung & Kisbianto \\
9 & Jogonalan & Prayoga & 22 & Jatinom & Parja \\
10 & Manisrenggo & Suratmi & 23 & Kemalang & Suratmi \\
11 & Karangnongko & Suratmi & 24 & Klaten Selatan & Romdloni \\
12 & Ngawen & Parja & 25 & Klaten Tengah & Mujiono \\
13 & Ceper & Adi Kurniawan & 26 & Klaten Utara & Sari Setyaningsih \\
\hline
\end{tabular}


Gerakan pengendalian hama dari setiap wilayah kecamatan dipimpin oleh penanggung jawab POPT-PHP kecamatan dengan koordinasi bersama kelompok tani dan PPL pada area sasaran dan juga berdasarkan hasil pengamatan petugas POPT-PHP. Gerakan ini dinamakan Gerdal atau Gerakan Pengendalian. Berdasarkan hasil pengamatan di lapang, pengendalian hama yang dilakukan masih dominan menggunakan pestisida kimia. Menurut Mariyono (2006) konsep PHT di Indonesia salah satunya adalah pengamatan berkala, dan menurut Wulanjari, et al. (2007) penggunaan pestisida dalam pengendalian menggunakan konsep PHT masih diperkenankan namun penggunaannya dibatasi dan hanya boleh menggunakan pestisida yang mudah terurai. Berdasarkan literatur tersebut maka pengendalian menggunakan pestisida kimia yang dilakukan oleh DPKPP Kabupaten. Klaten sudah mendukung konsep PHT karena penggunaan pestisida sudah menghindari sistem kalender dan diganti dengan menggunakan pengamatan berkala.

Pestisida yang digunakan berbeda-beda tergantung dari jenis hama yang menjadi sasaran. Wereng Batang Coklat dikendalikan dengan pestisida berbahan aktif Metharizium spp dan Beauveria bassiana. Pengaplikasian pestisida ini menggunakan metode semprot. Penggerek batang menggunakan beberapa merk pestisida dengan bahan aktif dimehipo $400 \mathrm{~g} / \mathrm{l}$, Tembaga Oksida 56\%, Bacillus thuringiensis dan Serratia sp dengan menggunakan metode semprot. Tikus menggunakan beberapa pestisida dengan bahan aktif buprofezin $100 \mathrm{~g} / \mathrm{l}$, belerang 66\%, dan Coumatetralyl 7,5 g/kg. Pengaplikasian pestisida ini dengan cara dibakar atau dicampurkan dengan gabah sebagai umpan.

Pengendalian hama selain menggunakan pestisida dilakukan dengan menggunakan agens hayati seperti Tricodherma dan Beauveria bassiana. Dua agens hayati ini termasuk dalam golongan fungi. Fungsi Tricodherma untuk menangani penyakit pada tanaman padi seperti blas yang disebabkan oleh jamur dan Beauveria bassiana untuk mengendalikan hama wereng, penggerek batang, dan kepinding tanah. Pengaplikasian kedua agen hayati ini menggunakan cara 
semprot. Penyemprotan Beaveria

bassiana harus kontak langsung

dengan hama sehingga hama yang terkena dapat menularkan ke hama lainnya.

Tabel 2. Hama dan Penyakit Padi di Kecamatan-Kecamatan di Kabupaten Klaten

\begin{tabular}{|c|c|c|c|c|c|c|}
\hline \multirow[t]{2}{*}{ No. } & \multirow[t]{2}{*}{ Kecamatan } & \multicolumn{5}{|c|}{ Hama dan Penyakit } \\
\hline & & $\mathrm{PB}$ & WBC & BLB & Blas & Tikus \\
\hline 1. & Prambanan & $\sqrt{ }$ & $\sqrt{ }$ & $\sqrt{ }$ & $\sqrt{ }$ & - \\
\hline 2. & Gantiwarno & $\sqrt{ }$ & $\sqrt{ }$ & - & $\sqrt{ }$ & $\sqrt{ }$ \\
\hline 3. & Wedi & $\sqrt{ }$ & $\sqrt{ }$ & $\sqrt{ }$ & $\sqrt{ }$ & $\sqrt{ }$ \\
\hline 4. & Bayat & $\sqrt{ }$ & $\sqrt{ }$ & $\sqrt{ }$ & $\sqrt{ }$ & - \\
\hline 5. & Cawas & $\sqrt{ }$ & $\sqrt{ }$ & - & - & $\sqrt{ }$ \\
\hline 6. & Trucuk & $\sqrt{ }$ & $\sqrt{ }$ & $\sqrt{ }$ & $\sqrt{ }$ & $\sqrt{ }$ \\
\hline 7. & Kalikotes & - & $\sqrt{ }$ & - & $\sqrt{ }$ & - \\
\hline 8. & Kebonarum & $\sqrt{ }$ & $\sqrt{ }$ & - & $\sqrt{ }$ & $\sqrt{ }$ \\
\hline 9. & Jogonalan & $\sqrt{ }$ & $\sqrt{ }$ & - & $\sqrt{ }$ & - \\
\hline 10. & Manisrenggo & $\sqrt{ }$ & - & $\sqrt{ }$ & $\sqrt{ }$ & - \\
\hline 11. & Karangnongko & $\sqrt{ }$ & - & - & $\sqrt{ }$ & - \\
\hline 12. & Ngawen & $\sqrt{ }$ & $\sqrt{ }$ & - & - & - \\
\hline 13. & Ceper & $\sqrt{ }$ & $\sqrt{ }$ & - & - & - \\
\hline 14. & Pedan & $\sqrt{ }$ & $\sqrt{ }$ & - & $\sqrt{ }$ & $\sqrt{ }$ \\
\hline 15. & Karangdowo & $\sqrt{ }$ & $\sqrt{ }$ & - & $\sqrt{ }$ & $\sqrt{ }$ \\
\hline 16. & Juwiring & $\sqrt{ }$ & $\sqrt{ }$ & $\sqrt{ }$ & $\sqrt{ }$ & $\sqrt{ }$ \\
\hline 17. & Wonosari & $\sqrt{ }$ & $\sqrt{ }$ & - & $\sqrt{ }$ & $\sqrt{ }$ \\
\hline 18. & Delanggu & $\sqrt{ }$ & $\sqrt{ }$ & $\sqrt{ }$ & - & $\sqrt{ }$ \\
\hline 19. & Polanharjo & $\sqrt{ }$ & $\sqrt{ }$ & $\sqrt{ }$ & - & $\sqrt{ }$ \\
\hline 20. & Karanganom & $\sqrt{ }$ & $\sqrt{ }$ & - & $\sqrt{ }$ & $\sqrt{ }$ \\
\hline 21. & Tulung & $\sqrt{ }$ & $\sqrt{ }$ & $\sqrt{ }$ & $\sqrt{ }$ & $\sqrt{ }$ \\
\hline 22. & Jatinom & $\sqrt{ }$ & $\sqrt{ }$ & $\sqrt{ }$ & $\sqrt{ }$ & - \\
\hline 23. & Kemalang & $\sqrt{ }$ & - & - & - & - \\
\hline 24. & Klaten Selatan & $\sqrt{ }$ & $\sqrt{ }$ & - & - & $\sqrt{ }$ \\
\hline 25. & Klaten Tengah & $\sqrt{ }$ & $\sqrt{ }$ & - & - & $\sqrt{ }$ \\
\hline 26. & Klaten Utara & $\sqrt{ }$ & $\sqrt{ }$ & - & - & - \\
\hline
\end{tabular}

Keterangan: PB: Penggerek Batang (Scirpophaga innotata)

WBC: Wereng Batang Coklat (Nilaparvata lugens)

BLB: Bacterial Leaf Blight (Xanthomonas campestris pv)

Blas (Pyricularia oryzae)

Tikus (Rattus argentiventer)

Sumber: Dinas Pertanian, Ketahanan Pangan, dan Perikanan Kabupaten Klaten

Menurut Wulanjari, et al., (2007) pengendalian hama terpadu merupakan suatu sistem pengendalian yang menghubungkan antara dinamika populasi dan lingkungan suatu jenis hama. Hal ini 
sejalan dengan konsep PHT yang dikemukakan oleh Mariyono (2006) di mana salah satu konsep PHT adalah mengoptimalkan musuh alami. Pengoptimalan musuh alami dapat mengembalikan keseimbangan populasi antara hama dan musuh alami sehingga secara alami hama dapat ditekan. Penggunaan pestisida kimia dapat dikurangi sehingga lingkungan dapat menjadi lebih sehat. Menurut Wilyus, et al., (2016) pestisida menimbulkan efek negatif yang berupa matinya organisme bukan pengganggu tanaman seperti musuh alami hama, organisme pengurai bahan organik, terjadinya resistensi atau ketahanan hama terhadap pestisida sehingga dapat menimbulkan ledakan hama, keracunan pada petani, meninggalkan residu kimia pada hasil produksi tanaman yang dapat meracuni konsumen dan menimbulkan pencemaran lingkungan terutama pada tanah. Menurut Sopialena pengendalian hayati hama dapat dilakukan dengan agensia hayati. Agensia hayati sendiri adalah semua jenis protozoa, serangga, bakteri, cendawan, virus serta organisme lainnya yang dalam tahap perkembangannya dapat dipergunakan untuk keperluan pengendalian hama dan penyakit (Sopialena, 2018).

Salah satu cara memanfaatkan agen hayati/pengoptimalan musuh alami dapat dilakukan dengan cara menanam tanaman refugia. Pengoptimalan penggunaan musuh alami untuk menangani hama padi yang dilakukan oleh DPKPP Kabupaten Klaten dirasa masih kurang Selama periode pengamatan yang dilakukan dalam tiga bulan belum didapati kegiatan yang mendukung penanaman refugia di areal lahan budidaya. Selain penanaman refugia dapat juga dilakukan pemberian penyuluhan maupun gerakan untuk membersihkan pematang sawah ataupun pematang sawah. Hal ini dapat menjadi pencegahan serangan hama, karena dengan pematang yang bersih maka tidak ada tempat persembunyian bagi hama. Sebagai contoh berdasarkan hasil pengamatan di Desa Beji Kecamatan Pedan, pematang sawah yag ada banyak ditumbuhi rumput liar dengan ketinggian $\pm 30 \mathrm{~cm}$ yang membuat pematang sawah ini menjadi sarang bagi hama tikus, dibuktikan dengan 
banyaknya lubang-lubang tikus sehingga harus dilakukan pengemposan menggunakan pestisida berbahan aktif belerang $66 \%$. Begitu juga yang terjadi di kecamatan Pedan di mana pematang sawah yang ada ditanami pohon pisang dan juga rumput-rumput liar yang menjadi tempat kesukaan tikus untuk bersarang. Hal ini terlihat pada saat gerakan "gopyokan" dilakukan, banyak sekali tikus yang bersarang di pohon pisang tersebut.

Pemanfaatan musuh alami dapat juga dengan membuat "RUBUHA" atau Rumah Burung Hantu. Rumah ini ditujukan agar burung hantu mau bersarang dan berkembangbiak di dalam rubuha. Lokasi pembuatan rubuha berada di tengah areal persawahan dengan tujuan burung hantu dapat bersarang di areal sawah dan dapat memangsa hama tikus. Serangan hama tikus biasa terjadi pada malam hari dan pada siang hari lebih banyak bersembunyi di dalam lubang. Pemanfaatan burung hantu dengan jenis Tito alba sebagai musuh alami tikus menjadi predator yang potensial karena burung hantu aktif pada malam hari dan juga karena fisiknya yang mendukung seperti yang diungkapkan oleh Baco (2011) dimana Tito alba memiliki tubuh yang besar, visual yang tajam, pendengaran yang tajam, kemampuan terbang senyap, dan mempunyai cakar dan paruh yang kuat dan lebar untuk menelan tikus. Menurut Widodo (2000) Tyto alba memiliki kemampuan memburu tikus yang baik dengan mengonsumsi 3-5 ekor tikus dan dapat memburu lebih dari jumlah yang dikonsumsi. Selain kemampuan berburu yang baik Tito alba juga mudah beradaptasi dengan lingkungan baru dan memiliki perkembangbiakan yang cepat. Dalam satu tahun burung ini dapat bertelur 2-3 kali masa bertelur dengan jumlah telur berkisar antara 6-12 dalam sekali masa bertelur.

Konsep PHT lain yang diungkapkan oleh Mariyono (2006) adalah menggunakan teknik budidaya tanaman sehat. Menurut Pasaribu, et al. (2017) tanaman budidaya sehat menekankan penggunaan varietas tahan hama, melakukan pergiliran tanaman, dan pergiliran varietas. Konsep budidaya tanaman sehat yang dilakukan oleh DPKPP Kabupaten Klaten dengan diberikannya bantuan benih kepada para petani dengan tujuan tanaman 
yang dibudidayakan seragam sehingga hama dan penyakit yang ada lebih mudah ditangani. Namun tujuan ini mengalami kendala dimana benih yang diberikan kepada para petani tidak ditanam seluruhnya bahkan ada yang dijual untuk keperluan pribadi. Dengan demikian maka monitoring bantuan benih kepada para petani harus lebih diperketat.

Tabel 3. Daftar Hama dan Penyakit Utama Padi di Kabupaten Klaten

\begin{tabular}{|c|c|c|c|c|}
\hline No & Hama & $\begin{array}{c}\text { Pestisida/ } \\
\text { Agens hayati }\end{array}$ & Bahan Aktif & $\begin{array}{l}\text { Metode } \\
\text { aplikasi }\end{array}$ \\
\hline \multirow[t]{5}{*}{1} & $\begin{array}{l}\text { Wereng Batang coklat } \\
\text { (Nilaparvata lugens) }\end{array}$ & $\begin{array}{l}\text { Beauveria } \\
\text { bassiana }\end{array}$ & \multirow{5}{*}{$\begin{array}{l}\text { Metharizium spp } \\
\text { Beauveria bassiana } \\
\text { buprofezin } 100 \mathrm{~g} / \mathrm{L}\end{array}$} & Semprot \\
\hline & & Metarizep & & Semprot \\
\hline & & & & Semprot \\
\hline & & Buprosida & & Semprot \\
\hline & & Mypcinta & & Semprot \\
\hline \multirow{3}{*}{2} & Blas & & \multirow[b]{3}{*}{ Mankozeb $80 \%$} & \\
\hline & (Pyricularia oryzae) & Tricoderma & & Semprot \\
\hline & & Dithane & & Semprot \\
\hline \multirow{8}{*}{3} & Penggerek Batang & & \multirow{8}{*}{$\begin{array}{l}\text { Dimehipo } 400 \mathrm{~g} / \mathrm{L} \\
\text { Dimehipo } 400 \mathrm{~g} / \mathrm{L} \\
\text { Dimehipo } 400 \mathrm{~g} / \mathrm{L} \\
\text { Tembaga Oksida } \\
56 \% \\
\text { Bacillus } \\
\text { thuringiensis } \\
\text { Serratia } \mathrm{sp} \\
\end{array}$} & \\
\hline & (Scirpophaga innotata) & Spontan & & Semprot \\
\hline & & Manuver & & Semprot \\
\hline & & Montaf & & Semprot \\
\hline & & Nordox & & Semprot \\
\hline & & & & \\
\hline & & BT-Plus & & Semprot \\
\hline & & & & Semprot \\
\hline \multirow{3}{*}{4} & Tikus & & \multirow{3}{*}{$\begin{array}{l}\text { Belerang } 66 \% \\
\text { Coumatetralyl 7,5 } \\
\mathrm{g} / \mathrm{kg}\end{array}$} & \\
\hline & (Rattus argentiventer) & Basmikus & & Bakar \\
\hline & & Racumin & & Umpan \\
\hline 5 & $\begin{array}{c}\text { Bacterial Leaf Blight } \\
\text { (Xanthomonas campestris } \\
\text { pv) }\end{array}$ & $\begin{array}{l}\text { Beauveria } \\
\text { bassiana }\end{array}$ & & Semprot \\
\hline
\end{tabular}

Sumber: Dinas Pertanian, Ketahanan Pangan, dan Perikanan Kabupaten Klaten

Menjadikan petani sebagai ahli

PHT di lahannya sendiri merupakan salah satu konsep yang juga dikemukakan oleh Mariyono (2006). 
Dalam upaya mendukung konsep ini maka langkah yang dilakukan oleh DPKPP Kabupaten. Klaten adalah dengan melakukan pertemuan dengan kelompok-kelompok tani dan mengadakan penyuluhan dengan pembicara berasal dari petugas PPL dan POPT-PHP setempat. Berdasarkan hasil pengamatan di lapangan, hal ini sudah dilakukan dengan diadakannya penyuluhan pada petani di Kecamatan Pedan tentang penanganan hama tikus, desa Buntalan Kecamatan Klaten Tengah mengenai permasalahan pupuk dan hama yang dihadapi oleh petani, dan juga pertemuan KTNA di desa Jomboran Kecamatan Klaten Tengah. Penyuluhan dilakukan tidak hanya disaat diadakan pertemuan saja, di setiap Gerakan pengendalian yang dilakukan juga selalu disisipkan penyuluhan tentang pengendalian hama maupun permasalahan yang dihadapi oleh petani. Selain itu DPKPP Kabupaten. Klaten juga

\section{Saran}

Progam penanaman refugia dan pembuatan rubuha perlu ditingkatkan serta dapat diadakan progam pengenal dan pelatihan pembuatan PGPR (Plant Gowth mengadakan progam SLPHT (Sekolah Lapang Pengendalian Hama Terpadu) di mana progam ini memberikan pengetahuan bagi para petani tentang bagaimana cara menerapkan pengendalian hama dengan menggunakan sistem PHT.

\section{KESIMPULAN DAN SARAN}

\section{Kesimpulan}

Kegiatan gerakan pengendalian hama dan penyakit padi di Kabupaten Klaten yang dilakukan oleh DPKPP Kabupaten Klaten telah mendukung empat konsep utama PHT yaitu budidaya tanaman sehat, mengoptimalkan musuh alami, pengamatan berkala, dan menjadikan petani sebagai ahli PHT di lahannya.

Pengendalian hama yang dilakukan masih memerlukan beberapa perbaikan seperti peningkatan kuantitas progam penanaman tanaman refugia dan pembuatan rubuha.

Promoting Risobacter) mengingat ketersediaan pupuk kimia yang mulai dikurangi jumlahnya sehingga diharapkan penggunaan PGPR dapat membantu mencukupi kebutuhan hara tanaman dan perlahan 
memperbaiki tanah. Penjadwalan gerakan pengendalian (gerdal) perlu dikoordinasikan lebih baik dengan petugas PPL dan kelompok tani setempat serta pemantauan saat pelaksanaan gerdal dapat lebih ditingkatkan sehingga hasil Gerakan dapat dicapai dengan maksimal.

\section{UCAPAN TERIMA KASIH}

Terimakasih saya sampaikan kepada Dinas Pertanian, Ketahanan Pangan, dan Perikanan Kabupaten Klaten dan segenap staff yang telah mengizinkan saya untuk mengikuti dan mengambil data kegiatan pengendalian hama dan penyakit pada tanaman padi.

\section{DAFTAR PUSTAKA}

Anonim. 2020a. Statistik Indonesia 2020. Jakarta: Badan Pusat Statistik Indonesia.

Anonim. 2020b. Provinsi Jawa Tengah dalam Angka 2020. Semarang: Badan Pusat Statistik Jawa Tengah.

Baco, D. 2011. Pengendalian Tikus pada Tanaman Padi Melalui Pendekatan Ekologi. Sulawesi Selatan: Balai Pengkajian Teknologi Pertanian.

Prakosta, A.B.J., Y. Prasetyo, dan Haniah. 2017. Analisis Tingkat Produksi Padi dan Perhitungan Logistik Pangan
Berdasarkan Metode EVI (Enhanced Vegetation Index) dan NDVI (Normalized Difference Vegetation Index) Menggunakan Citar Sentinel-2 Tahun 2016. Jurnal Geodesi Undip. 6(4) : 263-273

Jayanti, M. 2011. Faktor- Faktor Yang Mempengaruhi Keputusan Petani Padi Sawah Menggunakan Benih Menurut Sumber Benih. Skripsi Program Studi Agribisnis. Fakultas Pertanian Universitas Sumatera Utara.

Manueke, J., B. H. Assa, dan A. E. Pelealu. 2017. Rekomendasi Teknologi Pengendalian Hama Secara Terpadu (PHT) Hama Tanaman Padi Sawah (Oryza sativa) di Desa Makalonsow Kecamatan Tondano Timur Kabupaten Minahasa. Jurnal LPPM Bidang Sains dan Teknologi. 4(1) : 23-34.

Mariyono J. 2006. Kontribusi Pengendalian Hama Terpadu pada Penurunan Penggunaan Pestisida: Kasur Produksi Padi di Yogyakarta. Jurnal Matematika, Sains, dan Teknologi. 7 (2):128-138.

Pasaribu, A. F., S. F. Ayu, dan H. Hasyim. 2017. Evaluasi Progam Penyuluhan Pengendalian Hama Terpadu (PHT) terhadap Produksi dan Pendapatan Petani Padi Sawah. Medan: Universitas Sumatera Utara.

Ratnasih, Y. U., E. Lestari, dan D. Padmaningum. 2020. Hubungan antara Karakteristik Petani dengan Persepsi Petani 
Terhadap Inovasi Penerapan Burung Hantu Tyto Alba sebagai Pengendali Hama Tikus Studi Kasus Desa Gempol Kecamatan Karanganom Kabupaten Klaten. Journal of Agicultural Extension. 44 (1) : 66.

Sopiaelena. 2018. Pengendalian Hayati dengan Memberdayakan Potensi Mikroba. Samarinda: Mulawarman University Press.

Siregar, E. S. dan F. E. Nasution. 2019. Peranan Pola Pengairan dan Metode Pengendalian Hama Tikus (Rattus argentiventer) terhadap Produksi Padi Sawah. Agohita Jurnal Agoteknologi Fakultas Pertanian Universitas
Muhammadiyah Tapanuli Selatan. 4 (2) : 44-52.

Widodo, S.B. 2000. Burung Hantu, Pengendali Tikus Alami. Yogyakarta: Kanisius.

Wilyus, Y. R, dan W. Yunita. 2016. Pengendalian Hama Terpadu (PHT) Biointensif Pada Tanaman Padi di Desa Senaning. Jurnal Karya Abdi Masyarakat. 1 (1): 35-42.

Wulanjari, M. E., E. Iriani, dan K. Anwar. 2007. Pelaksanaan Pengelolaan Hama terpadu (PHT) Padi di Desa Kluwan, Kecamatan Penawangan, Kabupaten Gobogan. Jurnal Ilmiah ESAI. 4 (1). 